\title{
STUDIE
}

\section{RUKOPISNÝ LITEVSKÝ SLOVNÍK V KONTEXTU ČESKÉ BALTISTIKY PRVNÍ POLOVINY 19. STOLETÍ: KONCEPČNÍ ZÁMĚR SLOVNÍKU A OTÁZKA AUTORSTVÍ}

\author{
Anna Tollarová (Praha)
}

The Handwritten Litevský slovnik [Dictionary of the Lithuanian Language] in the Context of the Czech Baltic Studies in the First Half of the 19th Century: The Conceptual Plan of the Dictionary and the Question of Authorship

\begin{abstract}
This study focuses on the manuscript Litevsky slovnik [Dictionary of the Lithuanian Language] (shelf mark IV A 11), kept at the Department of Manuscripts and Early Printed Books of the National Museum Library. This handwritten lexicographic relic is dated to the first half of the 19th century and contains 1,701 entries. The nature of the Lithuanian Dictionary determines its significance. It is a comprehensive and complete philological study (organised alphabetically from $A$ to $\check{Z}$ ) that tries to answer crucial questions of Balto-Slavic relations. This article places the Lithuanian Dictionary within the context of Czech Baltic studies, particularly focusing on the matter of its authorship. Concerning this question, the article builds on previous research, in which F. L. Čelakovský was suggested as the likely author of the Dictionary. It updates previous research and adds new findings revealed by a professional handwriting analysis. A separate chapter focuses on the nature of the work, demonstrating the character of the Lithuanian Dictionary on several examples.
\end{abstract}

Keywords: Litevský slovnik [Dictionary of the Lithuanian Language] - František Ladislav Čelakovský - lexicography - National Revival - Lithuanistics Balto-Slavic relationships

\section{Úvod}

V tomto článku se budeme věnovat analýze tzv. Litevského slovniku, rukopisu uloženého v oddělení rukopisů a starých tisků Knihovny Národního muzea pod signaturou IV A 11. Jedná se o lexikografickou památku v rozsahu 30 listů velkého formátu $(21,5 \times 35,5 \mathrm{~cm})$, jež představuje ucelenou a dokončenou filologickou studii (řazenou abecedně od $A$ do $\check{Z}$ ) pocházející z první poloviny 19. století. Slovník obsahuje celkem 1701 hesel, z toho 1643 hesel s českým slovem na první pozici (v několika prŕpadech se v registru vyskytují lexémy z jiného, nejčastěji slovanského jazyka), na která navazují litevské ekvivalenty, gramatické poznámky, př́klady užití a často také etymologický výklad, a 4 hesla bez vysvětlující stati. Z celkového konceptu díla poněkud vybočuje 54 hesel označujících příbuzenské termíny, jež byla na základě sémantiky separována a uvedena hned úvodem Slovníku pod nadpisem Př́buzenství připojená (na fol. $2 \mathrm{v}$ ) $\mathrm{k}$ heslům pod písmenem A.

Výzkum památky byl doposud velmi skrovný. Jedním $\mathrm{z}$ důvodů je i pochybení při atribuci této archiválie ze strany asistenta Knihovny Národního muzea, historika Františka M. Bartoše, který Litevský slovnik v Soupisu rukopisných památek Národního muzea v Praze identifikoval nesprávně: „Podle něm. slovníku Nasselmannova z r. 1850“" Měl na mysli stěžejní lexikografické dílo poloviny 19. století G. H. F. Nesselmanna Wörterbuch der littauischen Sprache (Königsberg, 1850-1851). Na fol. 2r, jež následuje hned za titulním listem a obsahuje pomocnou lingvistickou informaci, je čitelný patřičný odkaz na publikaci z let 18501851. Právě tento odkaz, který se vázal pouze na termíny příbuzenství, F. M. Bartoš vztáhl na celý slovník. Chybná identifikace je patrná, vezmeme-li v potaz strukturu dotčených lexikografických děl: rukopisný litevský slovník má sled česko-litevský, zatímco Nesselmannův slovník litevsko-německý.

Pozornost badatelů Litevský slovník přitáhl relativně nedávno. Důvodem tohoto zájmu byla stat' Ilji Lemeškina Františeko Ladislavo Čelakovskio lietuviu kalbos žodynas ${ }^{2}$ z roku 2010, v níž autor poukázal na chybnou identifikaci v soupisu F. M. Bartoše a vyzdvihl řadu otázek vztahujících

\footnotetext{
* Tato publikace byla vydána s finanční podporou grantu poskytnutého GA UK č. 520317, s názvem Rukopisný slovník litevštiny Františka Ladislava Čelakovského, řešeného na Filozofické fakultě Univerzity Karlovy.

1 BARTOŠ 1926, s. 181.

2 Viz LEMEŠKIN 2010.
} 
se k záměru a povaze Slovníku a také k problematice autorství. Poprvé byla vyslovena domněnka, že autorem lexikografického díla mohl být František Ladislav Čelakovský. Širší zájem, který v současné době vzbuzuje zmíněná archiválie, dokládají zmínky v několika dalších publikacích nebo článcích, např. v předmluvě k Encyklopedii baltské mytolo$g i e^{3}$ od Marty E. Bětákové a Václava Blažka nebo v článku Vaidase Šeferise Kristijono Donelaičio kūryba čeku filologijos akiratyje. ${ }^{4} \mathrm{~V}$ roce 2016 byl Slovnik coby lexikografické dílo F. L. Čelakovského zařazen do bibliografického přehledu dějin české baltistiky. Autoři podrobné Bibliografie české baltistiky - Jindřich Čeladín, Václav Blažek, Tereza Kabeláčová a Eva Seitlová - mu věnovali zvláštní pozornost: „Za zakladatele české baltistiky je považován F. L. Čelakovský, jenž svoji sbírku slovanského zpívaného folklóru doplnil reprezentativním vzorkem litevských písní (první vydaní roku 1827). Pro tento účel se naučil litevsky podle Ruigisovy gramatiky z roku 1747 a ze sborníku L. Rėzy (1825) přeložil 72 písní do češtiny. Další velmi důležité dílo Čelakovského je Litevský slovnik, na kterém pracoval od 20. let 19. století až do smrti. [...] Bohužel nestihl svou práci dokončit, a proto Slovník zůstal pouze v rukopisné podobě. " ${ }^{5}$ Autoři odkazují na práci I. Lemeškina, na kterou navazuje rovněž tato studie. Autorka předkládaného článku se taktéž této problematice již věnovala: shrnula, doplnila a navrhla řadu dalších argumentů poukazujících na postavu F. L. Čelakovského coby původce, a sice ve své bakalářské práci Rukopisný slovník litevštiny z první poloviny 19. století z Knihovny Národního muzea. ${ }^{6}$

Důležitost Litevského slovníku, jak je patrné z výše uvedeného citátu z Bibliografie české baltistiky, je podmíněna dobou jeho vzniku, do níž se datuje samotný počátek české lithuanistiky coby vědní disciplíny. ${ }^{7}$ Kromě toho současného badatele překvapuje markantní povaha tohoto lexikografického díla. Nejde totiž o obyčejný slovník překladový, jaký by se v té době očekával spíše, ale o zevrubnou lingvistickou studii, jež usiluje o vysvětlení stěžejní otázky baltoslovanských jazykových/kulturních vztahů. Specifický lingvistický rozměr vede autora Slovníku ke zmapování různorodých a hojně zastoupených baltoslovanských lexikálních shod. Práce tohoto rozsahu s takovýmto záměrem je zcela zásadní pro pochopení dějin české baltistiky a slavistiky a je důležitá pro porozumění české filologické scéně první poloviny 19. století ve vztahu k národnímu obrození.

Grantový projekt GA UK s názvem Rukopisný slovnik litevštiny Františka Ladislava Čelakovského (̌̌. 520317), od roku 2017 řešený na Filozofické fakultě Univerzity Karlovy, byl zaměřen na bližší prozkoumání Litevského slovníku. Hlavním cílem bylo probádání lexikografické památky v rovině autorství a v kontextu vývoje české baltistiky první poloviny 19. století. Kolektiv řešitelů rovněž usiloval o zpřístupnění Litevského slovníku pro širší odbornou veřejnost. V souvislosti se stanovením původce bylo nutné nechat vypracovat písmoznalecký posudek, jenž se promítl i do dílčích výsledků představovaných v této práci. V kontextu české baltistiky převážnou pozornost zaujal tvưrčí odkaz F. L. Čelakovského, ovšem se znatelným přesahem i k jiným filologům první poloviny 19. století. Analýza jednotlivých slovníkových statí byla prováděna s neustálým zřetelem k myšlenkám českého obrozence vyjádřených ve Čteních o počátcích dějin vzdélanosti národi̊v slovanských (Praha 1877) a v dalších pojednáních.

V rámci zpř́stupnění Litevského slovníku byla vytvořena elektronická databáze, jež vznikla díky vstřícné spolupráci ze strany Národního muzea. ${ }^{8}$ Databáze je volně k dispozici na adrese http://lsc.ff.cuni.cz.

Dále $\mathrm{v}$ tomto př́spěvku soustředíme pozornost na problematiku autorství lexikografického díla, na okolnosti vzniku Litevského slovníku v kontextu české baltistiky a na samotnou povahu lexikografického záměru.

\section{Autorství F. L. Čelakovského}

Důvody, které podnítily přiřknutí pravděpodobného autorství Litevského slovníku F. L. Čelakovskému, vycházely zejména ze studia písemností a publikovaných výstupů tohoto obrozence. Badatelé tak činili na základě podrobné analýzy literárních i vědeckých prací a dochované korespondence. Litevský slovník dobře zapadal do kontextu zájmů i filologických tezí této významné osobnosti české literatury a vědy.

Tyto důvody, které vzešly z analýzy předchozích badatelů a které neztrácejí na aktuálnosti ani pro náš výzkum, je možné rozdělit do pěti oblastí:

1) Osobní korespondence F. L. Čelakovského, z níž nejdůležitější je zejména nedatovaný fragment dopisu Josefa Vlastimila Kamarýta svému př́teli, tedy F. L. Čelakovskému.

2) Ukotvení Litevského slovníku v tvưrčím odkazu F. L. Čelakovského, zvláště s ohledem na práce, $\mathrm{v}$ nichž obrozenec pracuje s litevskou látkou.

3) Kontinuální koncepční souvislost s dalšími lexikografickými záměry F. L. Čelakovského.

4) Myšlenková totožnost patrná ve Slovniku a Čteních o počátcích dějin vzdélanosti a literatury národúv slovanských, jež se vztahuje k problematice společného baltoslovanského původu.

5) Navržení okruhu osobností, které teoreticky mohly takový Slovník sepsat (jmenovitě např. Karel Jaromír Erben, Pavel Josef Šafařík) a postupné vyloučení jednotlivců z pozic potenciálních autorů.

O stěžejních argumentech spadajících do každé ze zmíněných oblastí krátce pojednáme v následujících částech.

\footnotetext{
${ }^{3}$ V díle je uvedeno: „V poznámkách ke svým překladům litevských písní si Čelakovský všímá i několika litevských theonym. Podstatně více jich zaznamenává jeho litevský slovník, který bohužel zůstal v rukopise." Viz BĚTÁKOVÁ - BLAŽEK 2012, s. 20.

4 Viz ŠEFERIS 2009. Autor zde „Slovníku Čelakovského“ věnuje zmínku na s. 48 zejména v souvislosti s „donelaitismy“, které se v Litevském slovniku vyskytují.

ČELADÍN - BLAŽEK - KABELÁČOVÁ - SEITLOVÁ 2016, s. 305-306.

${ }^{6}$ Viz TOLLAROVÁ 2016.

7 ŘEHÁČEK 1981.

${ }^{8}$ Př́i této př́iležitosti vyjadřujeme Národnímu muzeu poděkování za poskytnutí kvalitních digitálních kopií zkoumané archiválie.
} 


\section{Korespondence F. L. Čelakovského}

Zásadním předpokladem pro přiřknutí autorství $\mathrm{F}$. L. Čelakovskému je již zmíněný datově blíže neurčený fragment dopisu Josefa Vlastimila Kamarýta Čelakovskému, kde se můžeme dočíst následující: „Ten Letawský Slownjk giž bych rád widěl hotowý z mnohých přjčin i proto abych gednau od tebe aspoň slowem pozdrawen byl.“9 Fragment onoho dopisu, který bohužel nebyl zařazen do edice Františka Bílého zahrnující korespondenci F. L. Čelakovského, ${ }^{10}$ byl poprvé představen $\mathrm{v}$ již zmíněném článku I. Lemeškina z roku 2010. ${ }^{11}$ Kamarýtův list byl nalezen $v$ řadě dalších dopisů, jež se staly podkladem pro několikasvazkovou publikaci Františka Bílého, proto se o důvodech jeho nezařazení lze jen dohadovat. Je možné, že editor nebyl schopen zmínku o „letawském“ slovníku ztotožnit s konkrétním známým (publikovaným či rukopisným) spisem F. L. Čelakovského, a proto - postrádaje vhodný komentář $\mathrm{k}$ tomuto nejasnému místu - ho zanechal bez povšimnutí.

Jelikož se jedná o významné dobové svědectví „pamětníka“, uveřejňujeme tento důležitý epistolární fragment ve vizuální (viz obr. 1) a dešifrované podobě v plném rozsahu:

Ten Letawský Slownjk giž bych rád widěl hotowý $z$ mnohých přjčin $i$ proto abych gednau od tebe aspoň slowem pozdrawen byl.

List mlad Jung. mne došel, a neyspjše tedy na gegich pozwánj swoljm, a je si z čeho wybrati.

Baron Vernier se těšil že mne listem twým obraduge zatím ono z toho nic.

Odesjlám s poděkow. Bowring. Polské národnj. - poř́de očekáwage zbjrku českau. Jestli gsem geg déle podržel twého mjněnj a powolenj rač odpustiti, mně se welmi ljbil, aspoň že tak pěkně tištěné nebo rozumèti tomu - u mne geště nenj řeč, budeli to kdy Bưh wj gá ne.

Nic neslyšǰs̆, gestli giž Solnohradské wydánj Waltera Skota počalo, že nic mi Neureutr. neposjlá. Nebo čeká na penjze ostatnj - a těch arči dotud nenj,

Zatjm ljbá tě

Twug (podpis)

Pro nás je směrodatná první věta uvedeného dopisu. Vyvozujeme z ní tato zjištění:

1) F. L. Čelakovský pracuje na litevském slovníku;

2) v této práci pokročil natolik, že se hovoří o „hotovém" slovníku;

3) odesílatel si preje být osloven litevsky a slovník má pomoci porozumění př́ípadnému pozdravení.

Dopis obsahuje řadu podnětů, na jejichž základě se lze pokusit o bližší dataci zkoumaného úryvku. Indicie nás vedou k závěru, že dopis musel být napsán někdy během října nebo listopadu 1827. Zejména o tom hovoří tyto okolnosti:

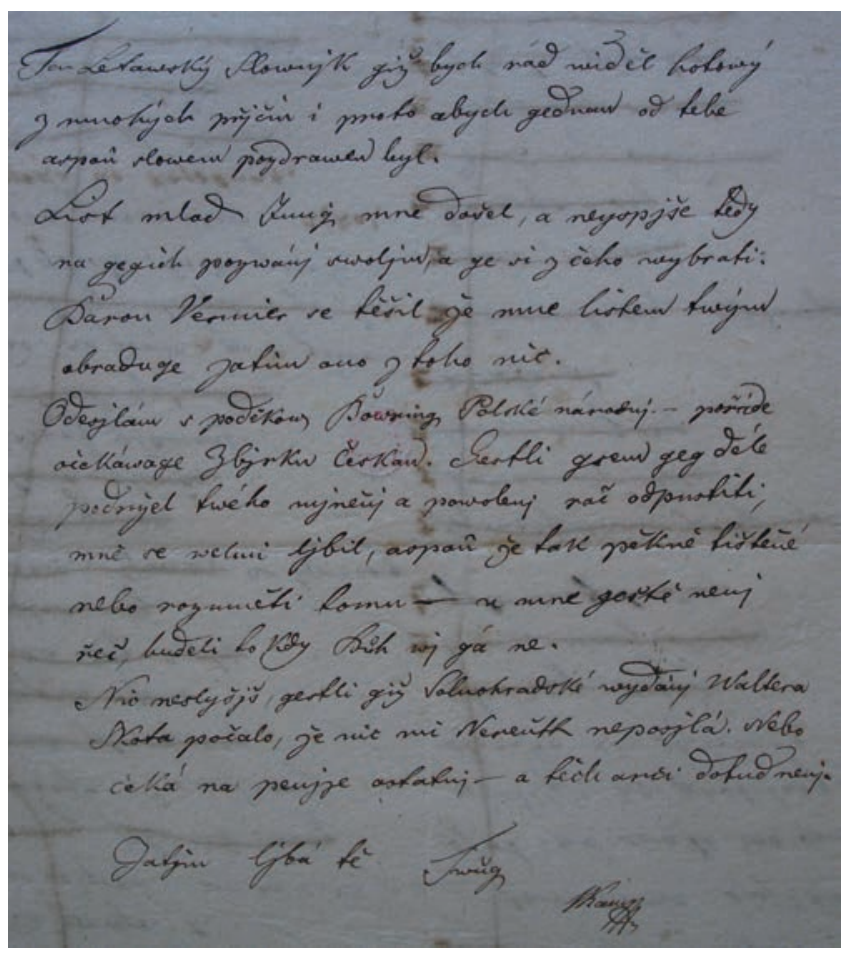

Obr. 1. Dopis J. V. Kamarýta F. L. Čelakovskému. (LA PNP, fond F. L. Čelakovský, fragment dopisu J. V. Kamarýta, nedatováno).

1) Horní hranici lze spolehlivě stanovit rokem 1833, kdy J. V. Kamarýt zemřel.

2) Adresant $v$ dopise zmiňuje barona Verniera, který mu měl předat dopis od F. L. Čelakovského. Tuto skutečnost je možné dát do souvislostí s listem F. L. Čelakovského datovaného 21. listopadem 1827, kde reaguje na lítost J. V. Kamarýta, že neobdržel dopis právě přes tohoto barona, větou: „Po bar. Vern. (gemuž mau poklonu složjš) gsem nemohl psáti a ljto mi bylo, ..."12

3) J. V. Kamarýt přes F. L. Čelakovského děkuje Johnu Bowringovi. Musíme mít na zřeteli, že k seznámení F. L. Čelakovského a J. Bowringa došlo na jaře 1827. F. L. Čelakovský pomohl J. Bowringovi při sestavení sbírky: Wýbor z básnictví českého: Cheskian Anthology being a history of the Poetical Literature of Bohemian with translated speciems, která v Londýně vyšla roku 1832. Do této antologie byly vloženy básně J. V. Kamarýta. Můžeme se domnívat, že ve zmíněném dopise J. V. Kamarýt prostřednictvím F. L. Čelakovského děkuje J. Bowringovi za zařazení svých básní do této sbírky. Ostatně ve svém listu z 24. července 1827 F. L. Čelakovský uvádí pasáž, z níž lze usuzovat o probíhající korespondenci s anglickým překladatelem:

\footnotetext{
${ }^{9}$ LA PNP, f. F. L. Čelakovský, fragment dopisu J. V. Kamarýta, nedatováno. Poznámka: Ve fondech F. L. Čelakovského a J. V. Kamarýta jsou dopisy řazené podle odesílatelů; jednotlivé položky nemají přiřazenou signatura ani přírůstkové číslo, proto dále uvádíme místo uložení, název fondu, konkrétní dopis podle adresanta s přesnou datací tohoto dopisu.

10 BÍLÝ 1907-1935.

${ }^{11}$ LEMEŠKIN 2010, s. 103-106.

${ }^{12}$ LA PNP, f. J. V. Kamarýt, dopis F. L. Čelakovského ze dne 21. listopadu 1827.
} 
„Poslyš, co powjdá [Bowring] o českých národnjch pjsnjch. [...] Bowring jewj wůbec welikau ljbost nad našimi věcmi, - a piše, žiwli bude kolikos geště měsíců že nebude wjce literatura česká u Angličanů neznáma."13

4) J. V. Kamarýt se zmiňuje, že očekává českou sbírku polských národních písní. Je na místě usuzovat, že tím míní třetí díl Slovanských národnich pisní (1827). O edičním záměru uchystat třetí svazek F. L. Čelakovský informuje v dopise z 27. března 1827. „Po swátcjch hodlám pak prohlédnouti swé národnj zápisky a podjwati se, gižli čas, stlaukati na třetj djlek. "14 V této souvislosti je pro nás směrodatný dopis z konce ř́jna téhož roku, kde F. L. Čelakovský mimo jiné uvádí: „Zde ti posjlám gako na ukázku Zbjrku polskau, aby widěl gak česká wyhljžeti bude. Prohljdni gi, a brzy zas odešli, pak bude wůle twá, pošlu i rusk. i srbsk." ${ }^{\text {"15 }}$

5) J. V. Kamarýt váhá nad datem vydání své sbírky. Jeho České národnj duchownj Písně. Djl prwnj sebrané od Jos. Wlast. Kamarýta vyšly roku 1831. Určuje tak další pevný mezník, do kdy námi analyzovaný dopis musel vzniknout.

6) Při porovnání dopisů J. V. Kamarýta z roku 1827 zjišt’ujeme, že dopisy za tento rok jsou psané na papír stejné kvality, resp. obsahující identický vodoznak.

7) Zmínky o solnohradském vydání Waltera Scotta a o pozvání obdrženém v podobě „listu mladého Jungmanna“ nápomocné nejsou, nebot' $v$ prŕṕpadě listu není zřejmé, o jaký druh pozvání se jednalo, v př́ípadě vydání se nepodařilo dohledat informaci o žádném odpovídajícím díle vydaném v Salzburku během zvažovaného časového úseku.

8) Nakonec je pro nás podstatné, že v dopise ze dne 4. března 1826 F. L. Čelakovský skutečně oslovuje svého prítele litevsky. Jedná se o oslovení Smagurci manám miělausám Kamarytui. ${ }^{16}$ Litevský pozdrav, naprosto ojedinělý v sestavě dopisů tohoto obrozence, doprovází texty čtyř litevských dain, jež byly přeložené do češtiny podle sbírky L. J. Rhèsy (1825). Jak již bylo zmíněno výše, F. L. Čelakovský tuto sbírku přeložil a pod názvem Litevské národní písně vydal v Praze roku 1827 a zasloužil se tak o první překlad litevských dain do cizího jazyka. Dedikaci lze interpretovat následujícím způsobem: ,Zvídavci mému nejmilejšimu Kamarýtovi. " 17 Oslovení tohoto druhu dokonale koresponduje s přáním být osloven litevsky, jež obsahuje blíže nedatovaný úryvek dopisu J. V. Kamarýta.

Poslední argument, jenž přispívá k chronologickému zařazení problematické archiválie, samozřjejmě nelze považovat za zcela relevantní. Přání obdržet oslovení v litevštině a litevské oslovení známé z roku 1826 nemusí navzájem souviset, Kamarýtovo přání (třeba i opakované) tedy mohlo pocházet i z jiné, dřivější či pozdější doby. Je nutné brát v úvahu i další možné výklady, např̀. že J. V. Kamarýt neměl na mysli pozdrav psaný, ale pozdrav slovní během očekávaného osobního setkání. Tak či onak tato indicie zároveň s dalšími uvedenými okolnostmi vymezuje rámcový časový úsek: 1826-1831, kdy dalším zúžením za pomoci dopisů z let 1827 docházíme $\mathrm{k}$ závěru, že dopis s největší pravděpodobností vznikl během října nebo listopadu 1827

\section{Litevský slovník v kontextu literárních a lexikogra- fických děl F. L. Čelakovského se zvláštním zřetelem na koncepci baltoslovanských kulturních a jazykových vztahů}

Zájem o jazykozpyt F. L. Čelakovský projevoval od počátku svých studií. Sám se vzdělával v různých živých a zaniklých jazycích (jmenovitě např. v řečtině, latině, angličtině, francouzštině, italštině apod. a samožrejmě v různých slovanských jazycích: ruštině, slovinštině, polštině, polabštině aj.). Ve svém filologickém bádání upřednostňoval metodu srovnávací jazykovědy. Filologickému vývoji F. L. Čelakovského se důkladně věnoval F. Bílý ve své přednášce $O$ filologickém vývoji Fr. Lad. Čelakovského uveřejněné v Listech filologických roku $1899,{ }^{18}$ na kterou v tomto místě odkazujeme.

V kontextu určování autorství Litevského slovníku je potřebné brát v potaz jiné „spř́izněné“, tedy typologicky podobné lexikografické aktivity (podstatně známější) F. L. Čelakovského:

1) „Výpisky o př́buzenství gothských a slovanských slov“, které vytvářel během svého studia staré gótštiny. Tomuto tématu se mladý Čelakovský začal věnovat $\mathrm{v}$ návaznosti na studium staroslověnštiny, k němuž ho inspirovalo dílo Josefa Dobrovského Základy jazyka staroslovénského z roku 1822.

2) Slovník polabštiny, kterému se věnoval $v$ druhé polovině dvacátých let a o němž 12 . června 1827 píše Kamarýtovi: „Slovník polabský již jest sestavený a nyní začínám načisto pracovat a opisovat. “19 F. L. Čelakovský tento slovník doplněný gramatickým úvodem na počátku roku 1830 zaslal prezidentovi Císařské akademie věd v Petrohradě, Alexandru S. Šiškovovi, kterého již dříve požádal o sepsání předmluvy. Toto dílo $\mathrm{k}$ vydání připravil a roku 1901 vydal Vladimir A. Francev pod názvem Остатки языка славян полабских, собранные и объясненные Ф. Л. Челаковским. ${ }^{20}$

3) Práce označovaná jako „Anglico-Slavonian-Researches“, inspirovaná spoluprací s J. Bowringem, v níž

\footnotetext{
${ }^{13}$ LA PNP, f. J. V. Kamarýt, dopis F. L. Čelakovského ze dne 24. července 1827.

${ }^{14}$ LA PNP, f. J. V. Kamarýt, dopis F. L. Čelakovského ze dne 27. března 1827.

${ }^{15}$ LEMEŠKIN 2010, s. 105-106.

${ }^{16}$ BÍLÝ 1907-1909, s. 282.

${ }^{17}$ TOLLAROVÁ 2016, s. 17-18.

${ }^{18}$ Viz BÍLÝ 1899.

${ }^{19}$ HANUŠ 1855, s. 22; BÍLÝ 1907-1909, s. 311.

${ }^{20}$ Viz FRANCEV 1901
} 
F. L. Čelakovský porovnával „shodná“ slova anglická a slovanská. Tuto sbírku zaslal do Londýna roku 1828. Její osud v současnosti není znám.

4) Záměr sestavit tzv. všeslovanský slovník kořenů a etymologický slovník češtiny, který měl vyjít jako VI. díl k Jungmannovu slovníku. Oba záměry bohužel zůstaly nedokončeny. V roce 1851 vydal F. L. Čelakovský Dodatky ke slovníku Josefa Jungmanna, ve kterém dílo předchůdce obohatil osobitým způsobem: doplnil slova nová, rozšíriil stávající hesla o další významy a lépe doložil ta již sice uvedená, ale nedostatečně podložená. Samotné dílo Jungmannovo budí pozornost baltistů, nebot' na straně 651 u hesla zemělička nacházíme dvojsloví zeměličko-květeličko s patřičným lithuanistickým výkladem: „Zeměličko, Květeličko - jest podle litevského Žemyněle, Žiedekiele, mytologicky zosobněno, místo: Země květorodná - Čelakovského Lit. písně, s. 120،“21 Nejedná se o ojedinělý odkaz na baltskou látku $\mathrm{v}$ tomto mimořádném díle. Jak uvádí Jiřri Marvan ve svém př́spěvku pro sborník Pocta Čelakovskému, „lithuanismy byly pojaty jako součást české slovní zásoby, byly jakoby posilou procitající češtině, která se skutečným cizomluvům vyhýbala. Litevština, arcit', se necítila jako jazyk cizi'“.22

$\mathrm{Z}$ dalších děl F. L. Čelakovského je nutné zmínit jeho článek Jazykozpytné rozmlouvání o jménu Slovan, ${ }^{23}$ který vyšel roku 1837 v Časopise Českého musea. V tomto článku se pokouší etymologicky doložit, že slovo Slovan a člověk jsou stejného původu. Zjevná romantická motivovanost takového výkladu, jakož i nadšení pro etymologii mohou být dalším vodítkem k autorské identifikaci Litevského slovníku.

Specifikum lingvistických úvah F. L. Čelakovského vědce $\mathrm{v}$ zajetí dobových obrozeneckých snah - mapují knižní produkce tehdejšího profesora slavistiky na Pražské universitě: Mudrosloví národa slovanského v príslovích ${ }^{24}$ $\mathrm{z}$ roku 1852, Čtení o srovnávací mluvnici jazyků slovanských ${ }^{25} \mathrm{z}$ roku 1853 a Čtení o počátcích dějin vzdělanosti národi̊v slovanských ${ }^{26}$ vydané roku 1877.

Univerzitní přednášky ilustrují koncepci baltoslovanské jednoty v osobitém podání F. L. Čelakovského, kterou dokonale doplňuje, a na konkrétním materiálu prokazuje právě Litevský slovník:

„Větve litevské zajisté daleko i v osedlosti slovanské se prostíraly; a i to zdá se býti jisto, že Slované od věkův nejvíce v lůno tohoto národu se šírili s ním pomalu v celost splývajíce. Což v tom divného? Krajin prázdných bylo všude dostatek; příchylná povaha Litevského kmene k tichému životu a rolnictví dobře se shodovala s naší slovanskou, i mohl dobře oseděti jeden národ nejen vedle druhého, ale i mezi ním samým, jak toho posud u př. $\mathrm{v}$ Uhřích nám blízkých př́klady máme před očima.
Kam však dějepis náš sahá a co z něho víme, není stopy nejmenší o nějakém našem společenství na delší čas trvajícím s tímto národem, a pročež nezbývá nic jiného, leč té myšlence povoliti, že tato vzájemnost nepochybně sahá do oněch dob, o nichžto nestává žádné písemné památky.

$Z$ většího počtu takových slov, jenž se mi sebrati událo, uvádím zde jenom některá: švarný = szwarus, ,čistý, hezký'; náramný = nerammus, ,divoký, prudký'; sluka = slanké, lot. slohka; luňák = lingě id. weihe od lingau, ,kruhem se vznášeti‘; ožanka (bylina teucrium) = ožys ,kozel`, jak i nám rostlina ,kozlík‘ slove; zákampí: kampas, ,kout, stinné místo“; chomol = kamolys, ,klubko, vír'; krabatý = katrbůtas; klábositi = kalbu, ,mluviti ; kalběsis = řeč, ,povídání'; šarapatka $=$ szerpétos,, nýtek, drobeček'; loudati se $=$ lendu, ,váhavě jíti, lezti ‘ kmen = kaměnus; zvířetnice, večernice $=$ žvěrinně etc.

Anobrž marně bychom se namáhali některá naše místní jména a jména řek ze slovanštiny chtíti si vyložiti; v litevštině ale hned zvuk i smysl se otevře, u př. Úpa, Úpice, Opava: lit. uppě = řeka, potok; Labe od labas t. ,dobrá, živná‘ a tak i Ogra, Ohře, od geras, což též ,dobrý‘ znamená; Ploušnice, rríčka u Děčína do Labe padající, od plusze, rýkos (jako Rokytnice); místa Řisuty v rkvn. a ltm. kraji = lit. reszutis, ,ořech'; Lkouš a Lokšany od lokis, ,medvěd“ jako i Medvězí máme; Ula, Hula jm. muž. a Hulín, Hulice, lit. ůla, ,skála“ (Skála m. Skalky); Lobze v bo. plu. a lokt. kraji, od lobis, ,statek, dvůr‘; Doksy a Doksany: u Litvínův běžné mužské jméno Doksa už v 14. století přicházející. Podobných jmen na litevštinu ukazujících lze najíti také na Moravě, Slezsku, v Lužicích a jinde, z čehož viděti, jak široce národ ten v neznámých nám časích se rozhošt'oval a na jak skrovnou hrstku nyní sklesl." ${ }^{27}$

Ve věci určení autorství z výše uvedených příkladů pozornost zasluhují především ty lexémy, které nacházíme také v Litevském slovníku. Konkrétně se jedná o adjektivum švarný = szwarus, verba loudati se = lendu ,váhavě jíti, lezti““ a substantiva sluka = slankě; zákampí = kampas ,kout, stinné místo“; kmen = kaměnas (přestože ve Slovníku je toto slovo uvedeno jako femininum kamiena) a zviŕretnice, večernice $=$ zvěrinně.

$\mathrm{S}$ výše uvedeným pojednáním dobře koresponduje poznámka uvedená ve Slovníku u hesla řeka: uppẽ [,,řeka“] /sr. Úpa/. Autor Litevského slovníku se taktéž pokouší vysvětlit etymologii slova Odra, avšak nikoli od adjektiva geras „dobrý“, nýbrž od substantiva udra ,vydra“. Tento rozdíl by se však dal vysvětlit Čelakovského jazykovědným vývojem a možnou změnou názoru.

Shody mezi obsahem univerzitních přednášek a Litevským slovníkem jsou dobře identifikovatelné. Nutné je ovšem brát v úvahu, že přestože tyto názorové shody mohou podporovat hypotézu Čelakovského autorství, nemohou mít pro jeho určení jakožto původce Slovníku

\footnotetext{
${ }^{21}$ JUNGMANN 1839, s. 651.

${ }^{22}$ MARVAN 2004, s. 11.

${ }^{23}$ Viz ČELAKOVSKÝ 1837.

24 ČELAKOVSKÝ 1852

${ }_{25}^{25}$ ČELAKOVSKÝ 1853.

${ }^{26}$ ČELAKOVSKÝ 1877.

27 Tamtéž, s. 65-66.
} 
rozhodující povahu. Výkladová podobnost může být sekundární, vezmeme-li v úvahu, že počet posluchačů přednášek F. L. Čelakovského se počítal na stovky, proto podobné jevy lze očekávat i u autora, který byl učením Čelakovského bezprostředně ovlivněn.

Vezmeme-li však v úvahu jako celek Čelakovského překladatelskou činnost ( $\mathrm{z}$ níž se dobře vyjímá především překlad Litevských pisní z roku 1827), lexikografická díla (zvláště ta do roku 1831), badatelské zájmy a názorová hlediska, je zřetelné, že Litevský slovník do kontextu vědecké činnosti F. L. Čelakovského velmi dobře zapadá.

\section{Datace Litevského slovníku}

$\mathrm{K}$ problematice datace Litevského slovniku se vyjádř́me jen krátce. $\mathrm{Na}$ základě dat z korespondence, s ohledem na Čelakovského překladatelské zájmy i lexikografickou činnost můžeme vyslovit předpoklad, že je-li autorem Slovníku, pravděpodobně jej začal psát kolem roku 1825 a v dalších letech jej dokončoval.

Verze Litevského slovniku, s níž dnes pracujeme, musí být opisem původního díla, kterým bohužel nedisponujeme. $\mathrm{K}$ tomuto závěru docházíme na základě analýzy pravopisu užitého ve zkoumané památce.

V průběhu první poloviny 19. století bylo zavedeno několik reforem pravopisu, jejichž následkem se ortografická norma výrazně měnila. ${ }^{28}$ Podle pravopisu užitého ve zkoumaném díle soudíme, že analyzovaná verze Litevského slovníku byla sestavena nejdřive po roce 1842, s ohledem na převažující způsob psaní $<\mathrm{v}>\mathrm{a}<$ ou $>$ spíše až po roce 1849 . Pro určení horní hranice je zcela zásadní sekundární litevsko-německá výkladová vsuvka (excerpce pojmů příbuzenství) pořízená podle Nesselmannova slovníku během roku 1851. Nutno poznamenat, že F. L. Čelakovský tuto publikaci měl k dispozici od února $1851 .^{29}$ To by znamenalo, že základní text Slovníku byl opsán drríve, tedy před 13. únorem 1851.

\section{Jiní možní autoři Litevského slovníku}

S odkazy na baltštinu se setkáváme v řadě děl 19. století, v tomto ohledu Litevský slovník plně zapadá do kontextu své doby a dobře koresponduje s tehdejším zájmem o slovanskou a baltskou látku. Osobností, které by v daném časovém úseku eventuálně mohly pracovat na Litevském slovníku, však není př́liš̌ velké množství.

V první řadě je třeba zmínit a jako autora vyloučit Karla Jaromíra Erbena, jehož jméno nalézáme na titulní straně Litevského slovníku. Př́jmení je na toto místo vepsáno tužkou a s otazníkem, což prozrazuje nejistotu pisatele. Člověk, jenž tuto poznámku s pochybností zanechal, zřejmě jen hádal. Karel Jaromír Erben (1811-1870) je přední literát národního obrození, jehož inspirovala, stejně jako
F. L. Čelakovského, lidová slovesnost. Zabýval se rovněž mytologií, která ho přměla i k vypracování jednoho slovníku. Kritická edice děl tohoto obrozence z roku 2009 obsahuje Abecedni slovník slovanského bájesloví, na němž Erben pracoval od poloviny šedesátých let 19 . století. ${ }^{30}$ Je pravda, že se K. J. Erben ve své výzkumné činnosti dotýkal litevské látky, ovšem způsob, jakým s ní zacházel (nesrovnalosti a chyby během opisování jemu nesrozumitelné baltštiny), prozrazuje, že v oblasti lithuanistiky nebyl zběhlým odborníkem.

K. J. Erben působil v letech 1846-1851 jako první vedoucí tehdy zřízeného Archivu Vlasteneckého (od roku 1848 Českého) musea. Tato skutečnost nabízí i jiný možný způsob výkladu. Jako důvodná se jeví úvaha, že poznámka na titulní straně Litevského slovníku má spíše ryze pragmatický ráz a poukazuje na interní zacházení s touto položkou uvnitř archivu. Poznámka s otazníkem totiž může znamenat: „Co na to Erben? Jak on, jakožto archivář, tuto položku identifikuje?" nebo „Bude tato položka zařazena do Archivu Národního muzea?"

Podstatně pravděpodobnější by bylo autorství významného jazykovědce, historika a spisovatele první poloviny 19. století Pavla Josefa Šafaříka (1795-1861). Tento mezinárodně uznávaný odborník v oblasti etnografie a lingvistiky sepsal řadu významných děl ze široce pojímané slovanské filologie a dějin Slovanů. Společně s F. L. Čelakovským ho řadíme do tzv. zakladatelské generace ${ }^{31}$ české baltistiky. Jeho zájem o lithuanistickou látku dokládá mimo jiné i jeho korespondence. P. J. Šafařík byl jedním z adresátů, jimž významný jazykovědec August Schleicher, autor první vědecké gramatiky litevštiny Grammatik der lithauischen Sprache z roku 1856, zasílal své zprávy př́mo z Východního Pruska. ${ }^{32}$ Dopisy určené P. J. Šafaříkovi obsahují hojné a cenné údaje o litevských nářečích, lexiku i zpívaných a narativních žánrech litevského folklóru.

Univerzitní knihovník shromažd'oval pro vlastní potřebu baltistickou látku. V této souvislosti je nutné zmínit, že v osobním fondu Šafaříka pod signaturou sign. IX E 4 je uložen pozoruhodný rukopis datovaný rokem 1833, pojmenovaný jako Výpisky o jazyku litevském. Toto dílo je rozděleno na několik částí. Nejpodstatnější úsek představuje Výtah slov z Ruhigova slovníku stejnokořenných se slovanskými, ve kterém se vyskytuje přibližně 785 slovních statí, což je oproti Litevskému slovníku méně než polovina. Oproti Litevskému slovníku, kde je česko-litevské řazení a samotný sled lexémů nahodilý, nacházíme ve Výpiscích litevsko-české řazení, př̀ičemž litevský index je řazen abecedně. Nehledě na zásadní rozdíly existuje mezi Výpisky z roku 1833 a Litevským slovníkem z poloviny 19 . století těsná vazba.

Výpisky a Litevský slovník pracují se shodným lexikálním materiálem. Např. z litevských lexémů začínajících písmenem E se ve Slovníku objevují všechny, které jsou obsaženy ve Výtahu z roku 1833, z 90 hesel začínajících na $\mathrm{K}$ se jich

\footnotetext{
${ }^{28}$ O těchto reformách podrobněji pojednává např. SEDLÁČEK 1993. (Dostupné z: http://nase-rec.ujc.cas.cz/archiv.php?lang=en\&art=7120)

${ }^{29}$ LA PNP, fond: F. L. Čelakovský, Doklady, Rechnung der A. C. kronberger 'schen Buch-, Kunst- \& Musikalienhandlung (za leden 1852).

${ }^{30}$ Viz ERBEN 2009.

${ }^{31}$ Označení převzato z publikace: MARVAN - ŠTOLL 2004, s. 62. Do zakladatelské generace je kromě F. L. Čelakovského a P. J. Šafaříka dále řazen August Schleicher (1821-1868) a Leopold Geitler (1847-1885).

${ }^{32}$ Podrobněji viz LEMEŠKIN 2008, s. 63-102.
} 
ve Slovniku uplatňuje více než třetina apod. Jedním z důvodů je totožný zdroj, z něhož obě lexikografické práce čerpají. Tím zdrojem je bezpochyby Ruhigưv slovnik. Je zde ovšem i další pravděpodobný vztah. Výpisky z roku 1833 sice jsou psané rukou P. J. Šafaříka, ovšem autor Slovanských starožitností patrně nebude jejich původním tvưrcem. S největší pravděpodobností se jedná o opis dřivější studie, který P. J. Šafařík pro vlastní potřebu pečlivě pořídil právě v roce 1833 (v osobním fondu tohoto vědce se ostatně opisy různých užitečných pramenů vyskytují v hojné míře). Svědčí o tom některé chyby, jež se do textu dostaly během procesu opisování originálu. Autorem předlohy mohl být sám F. L. Čelakovský. Dosvědčuje to výrok, jenž se nalézá ve druhém svazku Slovanských národních písní z roku 1825: „Prošed téhož Ruhiga slownjk (owšem ne auplný) nalezl gsem wjce šesti set djlem stegnězněgjcjch, djlem gednokořenných slow se Slowanštinau, složená a odwozená nepočjtage."33 Výtah slov z Ruhigova slovníku stejnokořenných se slovanskými, jenž tvoří základ Výpiskủ, koncepčně a i svým rozsahem (kolem 600 základních lexikálních tvarů) dokonale koresponduje s údajem, který roku 1825 poskytl F. L. Čelakovský. $\mathrm{Z}$ tohoto důvodu je nanejvýš vhodné Výpisky považovat za prrípravný materiál ke Slovníku, tedy za prvotní impulz, jenž vedl k vypracování rozsáhlejšího lexikografického díla.

Je příznačné, že otázka původu Výpisků nás vede k postavě F. L. Čelakovského. Nehledě na to je P. J. Šafařík natolik odborně fundovaná osobnost, že ho nelze v souvislosti s rozhodováním o tom, kdo byl autorem Litevského slovni$k u$, vyloučit. Šafaříkův zájem o baltskou látku (lingvistickou, historickou, národopisnou) byl dlouhodobý a vážný, proto se skutečně mohl pustit do sepsání baltoslovanského etymologického slovníku. Kontradikční je ovšem samotné „provedeni“ Litevského slovniku. Míníme tím zřetelnou romantickou motivovanost tohoto díla. Považujeme za pravděpodobné, že by se obdobného výzkumného úkolu P. J. Šafařík chopil (jak prozrazuje komparace s jeho publikovanými pracemi) v jiné kvalitativní rovině. Tentýž úsudek pochopitelně platí i v prŕípadě A. Schleichera coby tehdejšího profesora srovnávací jazykovědy a sanskrtu.

Je samozrrejmé, že okruh potenciálních autorů je o něco širší. Bylo by možné zvažovat i další osobnosti jak z řad vrstevníků F. L. Čelakovského, tak i z množství žáků a následovníků prvního profesora slavistiky na Pražské universitě. Jelikož však nenacházíme důvodné podněty, které by dovolovaly přiřknout Litevský slovník jiné osobnosti, nepovažujeme za nutné se této otázce na tomto místě věnovat podrobněji.

\section{Písmoznalecký posudek}

Důvody, na jejichž základě přisuzujeme Litevský slovník F. L. Čelakovskému, se tedy jeví poměrně zásadního charakteru. Přesto některé pochybnosti přetrvávají. Posílit či s jistotou vyvrátit je může odborný písmoznalecký posudek.

Za tímto účelem se řešitelský kolektiv výše uvedeného grantu obrátil na renomovaného soudního znalce $\mathrm{z}$ oboru písmoznalectví JUDr. Jiřího Straku, specialistu na ruční písmo, člena Československé společnosti pro písmoznalectví a současného předsedy Společnosti pro kriminalistiku. J. Straka se v oboru identifikačního zkoumání pohybuje více než čtyřicet let. Pracoval v Kriminalistickém ústavu v Praze, v Ústavu kriminalistiky a forenzních disciplín Vysoké školy v Karlových Varech a figuruje jako člen poradního sboru ministra spravedlnosti pro obor písmoznalectví. Je podstatné, že J. Straka má zkušenosti i s aplikací písmoznaleckých metod na látku historickou. Jako prríklad lze uvést zkoumání autorství povídky Jaroslava Haška (1883-1923) Vepřová historie (napsané na počátku 20. století), kterou v roce 2002 nalezl Oldřich Trégl v pozůstalosti po své matce. Povídka byla poprvé otištěna roku 2003 v literární př́loze deníku Právo.

První konzultace ohledně písmoznaleckého posudku započaly na podzim roku 2017, práce dále pokračovala v následujícím roce. Výsledný dokument obsahující závěr zkoumání byl řešitelskému kolektivu doručen 1. září 2018.

Řešitelský kolektiv byl hned na počátku spolupráce upozorněn, že práce s materiálem tohoto druhu naráží na řadu problémů, nebot' zkoumání památek 19. století z hlediska znaleckého zjištování pisatele je v České republice ve své podstatě unikátní. Úskalí spočívá ve volbě metodiky a prostředků. Když odborník pracuje se současným materiálem, vychází ze znalostí soudobého písmového úzu a aplikuje vhodné písmoznalecké nástroje. Když je nucen zpracovat látku starší, nemá dostatečný přehled o četnosti a významu jednotlivých znaků typických pro písmo určitého období. $Z$ tohoto důvodu je sice možné nalézt charakteristické znaky pro sporný rukopis, nicméně bez dalšího kontextu jim nelze jednoduše přiřadit identifikační hodnotu.

Pro vypracování písmoznaleckého posudku bylo tedy třeba vytvořit takové podmínky, kde by uvedené problematické aspekty byly v co největší možné míře eliminovány. Soudní znalec požádal řešitele projektu, aby kromě posuzovaného a srovnávacího materiálu (Slovníku a autografů $F$. L. Čelakovského) opatřili a předložili taktéž vzorky rukopisů dalších osobností, které psaly přibližně ve stejné době jako F. L. Čelakovský a byly tomuto obrozenci blízké svým profesním zaměřením i vzděláním. Účelem bylo, aby znalec mohl nejprve při analýze rukopisů těchto osob určit, zda jsou rukopisy ve zkoumané době dostatečně individualizované a obsahují znaky, které je dovolí od sebe spolehlivě rozlišit.

Řešitelský kolektiv za tímto účelem znalci poskytl ve formě kvalitních fotokopií následující rukopisně psané dokumenty:

1) Dopisy od K. S. Amerlinga, O. M. Bodjanského, K. Bronzińského, J. de Carra, P. P. Dubrovského, J. V. Kamarýta, V. S. Karadžiće, P. I. Köppena, F. Malewského, N. A. Měl'gunova, Františka Palackého a A. Šiškova, které jsou uloženy v pozůstalosti F. L. Čelakovského v Literárním archivu PNP.

2) Šafař́ki̊v opis Wýpiski̊ o gazyku litewském z 1833, uložený v oddělení rukopisů a starých tisků Knihovny Národního muzea (sign. IX E 4).

${ }^{33}$ ČELAKOVSKÝ 1825, s. 220-221. 
3) Protokoly Královské české společnosti nauk psané V. Hankou, uložené v Archivu Akademie věd České republiky (fond: Královská česká společnost nauk, karton 10, č. přír. 26).

4) Dopis Karla Jaromíra Erbena c. k. zemskému prezídiu z 8. 8. 1846, který je uložen v Archivu Národního muzea (sign. M6/44).

Ke srovnání předložená data umožnila tento závěr: ,již v době první poloviny devatenáctého století byly rukopisy dostatečně individualizované, aby mohly být od sebe odlišeny. Samotnému důkazu identifikace Františka Ladislava Čelakovského jako pisatele sporného textu tedy nebrání, že by jeho rukopis nebylo možné odlišit od rukopisů jiných osob. ${ }^{\text {‘34 }}$ Mimo jiné písmoznalec uvedl, že v rámci jiného výzkumného záměru by mohlo být prrínosné pokusit se rukopisy většího množství významných osobností (zvláště pocházejících z českých zemí) první poloviny devatenáctého století z hlediska míry individuality písma jednotlivých osob podrobným způsobem analyzovat a stanovit přesná pravidla. Takový přehled by měl kulturně-historický význam a též by posloužil při případném dalším identifikování jiného sporného rukopisu z té doby.

Jako materiál pro srovnání rukopisu autora Slovniku s autografem F. L. Čelakovského byly znalci poskytnuty fotokopie dopisů F. L. Čelakovského z rozsáhlého časového období (1818-1851), konkrétně se jedná o tyto prameny:

1) Dopisy J. V. Kamarýtovi z let 1818-1828 (LA PNP, f. J. V. Kamarýt),

2) Dopisy M. A. Přibilovi z let 1842-1845 (LA PNP, f. F. L. Čelakovský),

3) Dopisy Janu Plánkovi z let 1820-1851 (LA PNP, f. F. L. Čelakovský).

V nálezové části posudku J. Straka uvedl, že ,přri samotném porovnání rukopisu Litevského slovníku se srovnávacími vzorky písma Františka Ladislava Čelakovského byly nalezeny znaky různé hodnoty. Převahu mají znaky částečně nebo zcela shodné, nicméně byly nalezeny i znaky, které potřebnou míru shody nevykazují, a to hlavně ve zvláštní rovině zkoumání. [...] Mezi hlavní problémy při rozhodování o identifikační hodnotě jednotlivých znaků pak ale nepatří hlavně stavba jednotlivých částí at’ už v obecné, nebo zvláštní rovině zkoumání, jak tomu bývá $\mathrm{v}$ případech rukopisů ze současnosti, nýbrž využívání jednotlivých forem písmen z písařských norem...". 35

Částečně či plně shodné znaky J. Straka demonstroval v úvodu důkazové části posudku:

1) sklon: sporný rukopis i srovnávací texty jsou stabilně pravosklonné s hodnotami nejčastěji kolem $50^{\circ}$,

2) vázanost: stupeň vázanosti je střední jak ve sporném rukopisu, tak i ve srovnávacích vzorcích. Nejčastěji je pohyb přerušen pro napsání diakritických znamének, jen méně bez tohoto důvodu,

3) výškové poměry: střední pásmo je oproti hornímu a dolnímu často potlačené,

4) šířkové poměry: pro sporný rukopis i srovnávací vzorky hlavně blízké roku 1850 je nápadná převaha sekundárních šířek nad primárními, tedy šířek spojů mezi písmeny nad šířkami samotných písmen,

5) shody patrné $\mathbf{v}$ technice psaní:

a) technika psaní oválů písmen $<\mathbf{a}>,<\mathbf{0}>$ : zatímco ovály $<\mathrm{a}>$ jsou psány jednotahově $\mathrm{v}$ různých pozicích, jsou vedle jednotahových oválů $<_{0}>$ přítomny ve sporném textu i srovnávacích vzorcích ovály dvoutahové, tzv. „balené“, zejména v koncové pozici,

b) technika psaní $<\mathbf{d}>$ : v souladu s písařskou normou jsou horní části balené do levotočivé kličky či jejího náznaku, se sklonem vychýleným vlevo,

c) technika psaní $\langle\mathbf{g}>$ : ovály jsou menší, vyrovnané, kličky užší a delší, také vyrovnané jak ve sporném rukopisu, tak i ve srovnávacích vzorcích,

d) technika psaní $<\mathbf{j}>$ : časté jsou formy s ostřejším vrcholem a v dolním pásmu bez kličkového obratu, někdy jsou ale $\mathrm{v}$ dolním pásmu kličky,

e) technika psaní $<\mathbf{m}>,<\mathbf{n}>$ : arkádové formy nemají tendenci výrazněji přecházet $\mathrm{v}$ girlandové,

f) technika psaní $<\mathbf{p}>$ : vyskytují se jak formy bližší perličkovému druhu písma, tak i kurzívnímu,

g) shoda techniky psaní $<\mathbf{s}>$ při užití latinky, a také částečně při psaní $<\mathbf{t}>$,

h) shody, i když identifikačně málo významné, vykazují i písmena $<\mathbf{e}>,<\mathbf{l}>,<\mathbf{u}>$. ${ }^{36}$

J. Straka rovněž upozornil na znaky, které shodu nevykazují, nebo nejsou mezi sebou dostatečně v časovém souladu. Připomínáme, že předkládaná verze Litevského slovníku mohla být napsána někdy kolem roku 1850. Soudíme tak na základě užité normy pravopisu, nebot' písmena vyslovovaná jako [j] jsou psána jako $<\mathrm{j}>$, [g] je psáno jako $<\mathrm{g}>$, [v] jako $<\mathrm{v}>\mathrm{a}[\mathrm{i}]$ jako $<\mathrm{i}>$, stejně tomu je $\mathrm{v}$ případě dvojhlásky $<$ ou $>$. J. Straka uvedl, že vedle těchto znaků je možné nalézt varianty, které ve srovnávacích rukopisech hlavně kolem roku 1850 (konkrétně se jedná o dopisy z roku 1850 a z roku 1851) již F. L. Čelakovský nepoužívá, ale ve sporném rukopisu se vyskytují.

Obtížně vysvětlitelné znaky J. Straka postihl v těchto př́ípadech:

1) Tvary diakritických háčků: pro srovnávací texty i pro ty vzniklé kolem roku 1850 jsou příznačné háčky výrazněji otevřené vlevo, což se ve sporném rukopisu v takové míře rozhodně nevyskytuje.

2) Koncová adjustace: pro srovnávací vzorky i ty vzniklé kolem roku 1850 je obvyklé, že se v některých koncovkách vyskytuje výraznější protažení, což ve sporném rukopisu není možné nalézt.

3) Technika psaní z: pro sporný text jsou nejtypičtější varianty podle starších norem s kličkovým obratem pod základnou, ale ve srovnávacích textech datovaných kolem roku 1850 takové formy již nelze nalézt.

4) Kombinace st: $v$ těchto kombinacích jsou často ve sporném rukopisu stopy kurentu, což v rukopisech Františka Ladislava Čelakovského není možné nalézt již po dlouhou řadu let před rokem 1850.

\footnotetext{
${ }^{34}$ STRAKA 2018, s. 12

${ }^{35}$ Tamtéž, s. 15.

36 Tamtéž, s. 16-17.
} 
5) „Nabodeníčka“: pro sporný rukopis je v celém jeho rozsahu velmi př́iznačné, že za formou $<_{\mathrm{S}}>$ nikoliv kurentní je bud' přítomno malé znaménko (nejčastěji ve tvaru tečky či malého háčku), prríp. je o něj prodlouženo nasazení písmene, které po $<$ s $>$ následuje. To je ale pro běžný (obvyklý, spontánní) rukopis Františka Ladislava Čelakovského netypické. ${ }^{37}$

Vedoucí grantového projektu doc. PhDr. Ilja Lemeškin, Ph.D., na žádost J. Straky k těmto zjištěním poskytl vysvětlení, která by uvedené nesrovnalosti mohla vyložit:

„Slovník [...] měl soustavně vznikat v průběhu první poloviny 19. století. První zmínka o Letawském Slownjku F. L. Čelakovského je datovaná r. 1827, ovšem starším originálem, původně psaným starším pravopisem, bohužel nedisponujeme. ${ }^{38}$

Základní česko-litevský text lexikografické památky měl být patrně sepsán (či spíše opsán) během čtvrté dekády 19. století. Horní hranici umožňuje stanovit sekundární litevsko-německá výkladová vsuvka zařazená (ne dřive než v únoru 1851) do základního textu slovníku - excerpce pojmů př́buzenství. Nesselmannưv slovník z r. 1851 coby užitý tištěný zdroj je uveden na fol. 2r. Nutno zmínit, že titul Wörterbuch der littauischen Sprache, stejně jako německá výkladová část u termínů př́buzenství na fol. $2 \mathrm{v}$ jsou vepsané frakturou. Tato okolnost může být důležitá pro uchopení některých specifických písmových rysů.

Filologové 1. poloviny 19. století se vesměs opírali o lexikografická díla, která v průběhu 18. a 19. století vznikala na půdě Litevského semináře Královecké university (Albertus-Universität Königsberg). Největší uplatnění měly lexikografické práce Ph. Ruigyse (Lexicon GermanicoLithvanicum et Lithvanico-Germanicum, 1747), Ch. G. Milckého (Littauisch-deutsches und deutsch-littauisches Wörter-Buch, 1800) a již zmíněného G. H. F. Nesselmanna (Wörterbuch der littauischen Sprache, 1851). V Královci vydané slovníky, z nichž český autor před r. 1851 čerpal materiál relevantní pro svůj výzkum, byly tištěny švabachem. V 19. století se tímto tiskovým písmem tištěná němčina opisovala frakturou, ovšem litevština $\mathrm{v}$ kombinaci s češtinou v podání autora Litevského slovníku vyžádala užití antikvy. Rovněž je třeba si uvědomit, že v procesu psaní slovníku měla zrejmě vedoucí postavení právě litevština, autor tedy z dostupných pramenů excerpoval lexémy, které souzněly se slovanštinou. Litevština a její tištěná východopruská podoba měla primát, což se mohlo promítnout i v grafickém ztvárnění lingvistické předlohy. Převodem litevštiny do antikvy mohly vzniknout jisté ,nesrovnalosti“, např́íklad větší náchylnost ke spřežkovému psaní jednotlivých grafémů ( $<$ st $>$, $<$ sz $>,<$ sk $>,<$ sl $>$ apod.).

Obecně rukopis působí čitelným a ,vzorným‘ dojmem. Pisatel dbá na to, aby fixace litevských slov nevyvolávala pochybnost (tato, přehnaná preciznost se pak promítá i do češtiny; v rámci jednoho díla se litevská a česká část pochopitelně sjednocuje), proto mezi možnými variantami volí tu podobu grafému, jejíž fonetická hodnota je evidentní.
Je to pochopitelné, vezmeme-li v potaz, že cílový čtenář rukopisu (jiný filolog 19. století) či sazeč v tiskárně litevštinu neovládal, tedy nebyl schopen fonetickou hodnotu sporných znaků vydedukovat z kontextu. Projevuje se to, jak se zdá, mimo jiné $\mathrm{v}$ psaní písmena $<_{\mathrm{S}}>\mathrm{s}$ diakritickým znamínkem v pravém poli (srov. s užitím stejně varianty tohoto písmenka na titulní straně Ohlasu písní ruských z r. 1829).“" ${ }^{\text {“39 }}$

$\mathrm{S}$ přihlédnutím $\mathrm{k}$ těmto relevantním okolnostem se J. Straka vyjádřil k nálezům takto:

\section{„Ad 1. (Tvary diakritických háčků)}

Pokud jde o diakritické háčky, pak lze ve velmi rozsáhlém a časově rozprostřeném srovnávacím vzorku rukopisů Františka Ladislava Čelakovského nalézt i varianty, které nejsou otevřeny vlevo. Naprosto určující a hlavně platné v rukopisech datovaných kolem roku 1850 jsou ale háčky otevřené vlevo, což v té míře rozhodně sporný materiál nevykazuje. Přitom ani ze stanoviska doc. Lemeškina nelze dospět $\mathrm{k}$ tomu, že by to nějak mohlo souviset s eventuálními vlivy, které na rukopis Františka Ladislava Čelakovského, pokud je pisatelem Litevského slovníku, mohly mít okolnosti jeho vzniku, jak je doc. Lemeškin uvádí. Za současného stavu tedy není možné tento znak, který nelze označit jako shodný, spolehlivě vysvětlit.

\section{Ad 2. (Koncová adjustace)}

Pokud jde o koncovou adjustaci, tedy o její protahování v některých slovech srovnávacích materiálů, zatímco se tak neděje ve sporném rukopisu, tento znak má z celkového pohledu nízkou hodnotu. Jde jednak o to, že texty Litevského slovníku jsou psány s ohledem na prostor velmi úsporně, což by mohlo mít vliv na prodlužování, resp. neprodlužování koncové adjustace, jednak i když se hlavně ve srovnávacích vzorcích z roku 1850 a 1851 prodlužování vyskytuje, převažuje zakončení zkrácené typově odpovídající spornému rukopisu.

\section{Ad 3. (Technika psaní z)}

Technika psaní či užitá písařská norma pro psaní písmen $<\mathrm{z}>$ ve sporném rukopisu vychází v naprosté většině z norem platných před rokem 1849. Lze nalézt i jiné formy, ale ty zase písmenům z let nejméně od roku 1849 neodpovídají proporčně $[\ldots]$.

Na jedné straně je nutné konstatovat, že je tedy v užité normě písmene $<\mathrm{z}>$ mezi sporným rukopisem a srovnávacími vzorky nejméně od roku 1849 rozdíl, na druhé by vlivy, které na rukopis mohly mít podmínky, za nichž měl zřejmě vznikat, použití kurentní formy odůvodňovaly. Je ovšem třeba přiznat, že je to vysvětlení hypotetické, nikoliv prokazatelné ve vzorcích z časově odpovídajícího období.

\section{Ad 4. (Kombinace st)}

Jako u vysvětlení ad 3 je nutné i zde konstatovat, že se kurentní kombinace $<$ st $>$ ze sporného rukopisu již po delší časový úsek ve srovnávacích vzorcích Františka Ladislava

\footnotetext{
${ }^{37}$ STRAKA 2018, s. 21-22.

${ }^{38}$ LEMEŠKIN 2010.

${ }^{39}$ LEMEŠKIN 2018.
} 
Čelakovského nevyskytuje (z dostupných zdrojů již nebyla nalezena ani v březnu 1820). Protože toto spojení lze ale zaznamenat $\mathrm{v}$ písmu ovlivněném kurentem (do roku 1820), není možné vyloučit hypotézu doc. Lemeškina, že může jít o jakýsi přenos vlivu s ohledem na okolnosti vzniku Litevského slovniku, které ho zřejmě provázely.

\section{Ad 5. „Nabodeníčka“}

Konečně i pokud jde o tzv. „nabodeníčka“, nelze zásadně odmítnout hypotézu doc. Lemeškina, že je jejich př́tomnost ve sporném rukopisu dána snahou písmena dobře rozlišit pro účely tisku. Jednak je samožrejmě důležité, že doc. Lemeškin sám nabídl důkaz užití takového znaménka v rukopisu psaném Františkem Ladislavem Čelakovským, jak lze pozorovat na obr. 2, a nelze tedy ani konstatovat, že by se v rukopisu Františka Ladislava Čelakovského nevyskytovala nikdy.

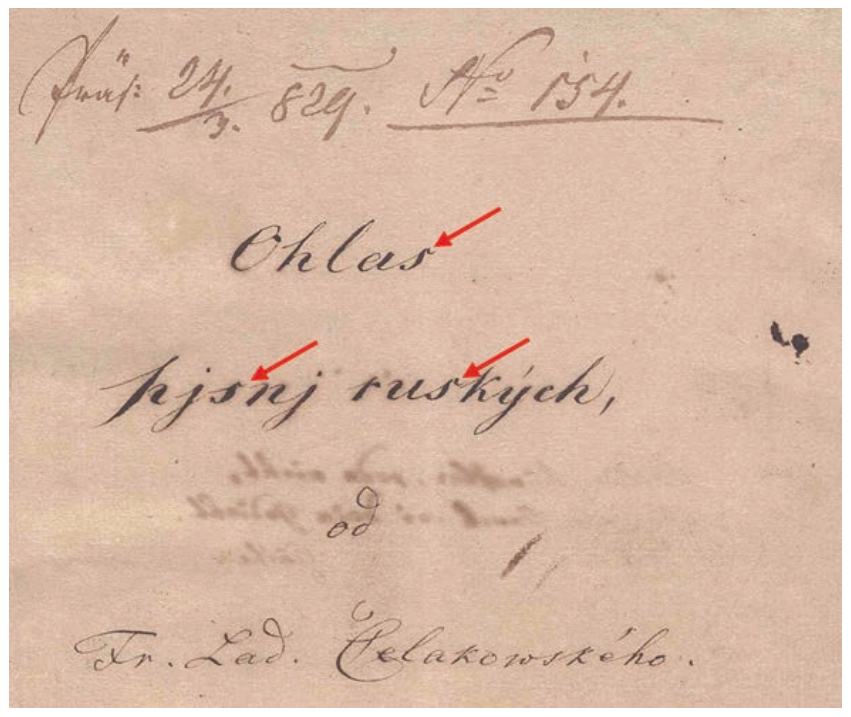

Obr. 2. „Nabodeníčka“ v rukopisu F. L. Čelakovského. Titulní strana „Ohlasu písní ruských“ z roku 1829 (STRAKA 2018, s. 26.).

Tuto hypotézu však mírně komplikuje fakt, že např. Josef Václav Kamarýt taková nabodeníčka používá na rozdíl od F. L. Čelakovského celkem běžně, jakkoliv jsou v textech formy dopisů, nikoliv v textech určených pro tisk, jak lze pozorovat na obr. 3 .

Pokud pak jde o pohled ze současné písmoznalecké praxe, zdá se obtížň možné, že by taková znaménka ve srovnávacích vzorcích vyhotovených již i dlouhou dobu před datací a i v době blízké dataci samé $(1850,1851)$ užíval jen sporadicky, a že by je v celém rozsahu Litevského slovníku využíval zřejmě bez výjimky. Z hlediska předpokladu významu dynamických stereotypů, na jejichž základě se rukopis vytváríi, by to byl pro současnou dobu neobvyklý výkon. Přiznat tomuto markantu hodnotu zcela spolehlivou by ale vyžadovalo velmi podrobné studium jak rukopisů Františka Ladislava Čelakovského, tak i jeho současníků."“40

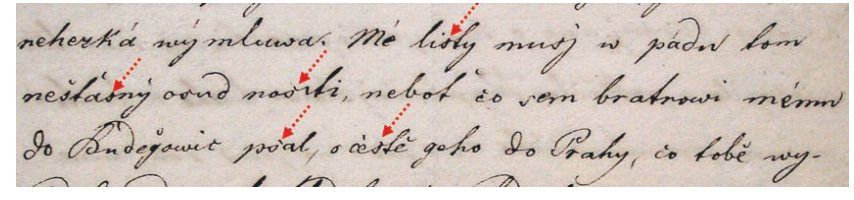

Obr. 3. "Nabodeníčka“ v rukopisu J. V. Kamarýta. Dopis J. V. Kamarýta (STRAKA 2018, s. 26.)

Za uvážení zmíněných ukazatelů J. Straka v důkazové části posudku uvedl:

„Z provedeného dokazování je patrné, že nebyly nalezeny znaky, které by dovolily rozhodnout kategoricky o tom, zda je František Ladislav Čelakovský pisatelem archiválie Litevský slovnik. Kromě toho, že nebyly nalezeny jen shody vysoké hodnoty, ale ani převažující rozdíly, rozhodnutí objektivně komplikují skutečnosti v posudku analyzované, vycházející z objektivních podmínek, resp. možností zkoumání rukopisu zřejmě vzniklého v polovině devatenáctého století. Na jedné straně existují některé znaky, jejichž výskyt nelze vysvětlit zcela spolehlivě (někdy jen za pomoci hypotéz), na druhé ovšem existují prokazatelné shody s rukopisem Františka Ladislava Čelakovského. $\mathrm{Z}$ důvodu poměrně časté a někdy i zásadní změny písařské normy $\mathrm{v}$ té době a nemožnosti za současného stavu poznání kategoricky vysvětlit zákonitosti vlivu těchto změn na konkrétního písaře ale nemají shody takovou hodnotu, jakou by jim bylo možné přiznat, pokud by byl zkoumán rukopis ze současnosti. Ze všech uvedených důvodů bude nejobjektivnějším vyjádřením možností písmoznaleckého zkoumání rukopisu Františka Ladislava Čelakovského jako pisatele archiválie Litevský slovník stanovení následujícího kladného závěru $\mathrm{v}$ rovině střední pravděpodobnosti. “"

Následkem toho v části závěrečné J. Straka vyjádřil tento výsledek posuzování:

„Předmětnou archiválii, tj. Litevský slovnik (sign. IV A 11), jehož originál je uložený v oddělení rukopisů a starých tisků Knihovny Národního muzea, pravděpodobně napsal František Ladislav Čelakovský, narozený 7. března 1799 a zemřelý dne 5. srpna 1852, jehož srovnávací rukopisy mi byly ke zkoumání předloženy. “42

\section{Litevský slovnik jako filologická studie: uvedení do problematiky}

Jak již bylo řečeno výše, Litevský slovník si za cíl klade vysvětlení stěžejní otázky baltoslovanských vztahů. Sepsané shody mají sloužit jako důkaz existence období společného soužití Baltů a Slovanů. $Z$ tohoto ohledu je nutné pristupovat i k rozboru jednotlivých statí slovníku. Autor v nich podléhá dobovým kontextům, zejména se to projevuje náchylností $\mathrm{k}$ ideologicky motivovaným výkladům, a i bez důkladnější etymologické analýzy je z hlediska aktuálnosti soudobého vědeckého poznání pozorovatelné, že je Litevský slovnik poněkud zastaralý a že ve vícero prŕpadech jsou domněnky

\footnotetext{
${ }^{40}$ STRAKA 2018, s. 24-27.

41 Tamtéž, s. 27.

42 Tamtéž, s. 27.
} 
autora Slovniku mylné. V žádném prrípadě mu však nelze upřít, že v některých jiných prŕpadech postihl i legitimní shody.

Litevský slovník obsahuje statě $\mathrm{v}$ následujícím abecedním pořadí a počtu: A (5 statí), Příbuzenství (54 statí), B (108 statí), C ( 9 statí), Č (54 statí), D (99 statí), F (4 statě), J (34 statí), H, ž (75 statí), CH (23 statí), K (147 statí a 1 heslo bez statě), L (71 statí), M (107 statí a 1 heslo bez statě), N (47 statí), O (46 statí), P (179 statí), R (82 statí a 1 heslo bez statě), S (192 statí), Š (38 statí), T (73 statí), U (21 statí a 1 heslo bez statě), W (133 statí), Z (49 statí), Ž (48 statí). Hesla jsou $\mathrm{v}$ registru $\mathrm{v}$ rámci své skupiny řazena nahodile. Některé statě nabízí různé výklady stejného slova na první pozici (napríklad slovo had se na první pozici vyskytuje trrikrát).

Podrobnější pojednání o charakteru jednotlivých statí je k dispozici na webové stránce databáze (http://lsc.ff.cuni. $c z$ ). V této databázi jsou jednotlivá hesla rozdělená do patřičných kategorií, kteréž samy o sobě mohou vhodně ilustrovat specifikaci záměru F. L. Čelakovského. Kategorie můžeme rozdělit do čtyř základních okruhů:

1) obecné informace;

2) slovní druhy;

3) tematické okruhy;

4) etymologická oprávněnost.

Okruh Obecné informace postihuje zejména faktické, popisné či obsahové údaje. Můžeme zde vyčlenit kategorie jako: „německy psaný text“" zahrnující statě, $v$ nichž se vyskytuje text v německém jazyce; „nečeské slovo na první pozici“; „text z jiného dalšího jazyka (ve stati)“, čímž je myšlen jiný jazyk, než je čeština, litevština nebo němčina, nejčastěji se jedná o latinu, polštinu, řečtinu či lotyštinu; nebo kategorii „červené písmo“, jež postihuje statě, v nichž se nachází v originálu červeně podtržený ( $\mathrm{v}$ přepisu zvýrazněný) text.

Roztřídění do kategorií dle slovních druhů probíhalo podle české tradice (a to dle slova na první pozici), mimo toho zahrnuje kategorii „Sousloví, věta, fráze aj.“. V Litevském slovníku není ojedinělé, že se na první pozici vyskytuje sousloví (např. černá zvěř, hončí pes, květná neděle aj.). Z hlediska slovních druhů se jedná zejména o substantiva (která tvoří nadpoloviční většinu všech hesel na první pozici), adjektiva a verba.

Co se týče tematických okruhů, dají se ve Slovniku vyčlenit čtyři další samostatné skupiny, na něž je možné zaměřit pozornost badatele: 1) theonyma, 2) mythonyma, 3) fytonyma, 4) zoonyma; které dobře korespondují s folkloristickými a botanickými zájmy F. L. Čelakovského.

Okruhy etymologické oprávněnosti nabízí orientační rozdělení na základě pravděpodobné legitimnosti daných tvrzení s patřičným ohledem na současný výklad. Z hlediska záměru Slovníku stojí za pozornost statě dokládající baltoslovanskou vzájemnost, zajímavé jsou zejména ty ovlivněné dobovým obrozeneckým kontextem.

$\mathrm{V}$ následující části této kapitoly uvedeme několik vybraných př́kladů, které snahy autora (a povahu díla) dobře ilustrují. Zvolili jsme hesla biliti, boží dřevce, cibule a hvězda.
Heslo biliti vhodně ilustruje obrozeneckou povahu díla. Heslo boži dřevce je sousloví, nabízí stat' postihující sémantickou shodu s litevským protějškem a taktéž představuje botanické pojmenování. Heslo cibule ukazuje na jeden z množství ve Slovníku se vyskytujících slavismů. Poslední heslo, hvězda, patř́ ke stati, kde autor postihl významnou baltoslovanskou shodu a která zároveň obsahuje jedno z mnoha ve Slovníku se vyskytujících mytonym. Na tomto prostoru není naším cílem poskytnout důsledný etymologický rozbor každé z těchto statí. Nabízíme krátkou interpretaci s patr̆ičným ohledem na dobu vzniku zkonfrontovanou s výklady významných jazykovědců, na jejichž dílech staví současná etymologie, a to zejména Wojciecha Smoczyńského a Václava Machka.

Heslo: bíliti ( 95 . v celkovém pořadí, 36 . ve skupině pod písmenem B):

„,bíliti, běliti, balu n. bastu, balti; baltas, -a, bílý; dobrý, dobrosrdečný; balti žmones, dobří lidé; balta galwa, dobrá duše (mluví se k osobě ženské; baltokas, - $a$, bělavý; baltummas, -o, m. běloba; bílek; baltybe, bílá barva; bẽlsti, baltoju, -oti; baltinu, -inti, bíliti.“43

V této stati pozorujeme snahu autora vysvětlit skrz litevštinu význam původního adjektiva bílý. Snaží se doložit, že tento lexém označoval nejen barvu, ale i kvalitu, tedy že „,co je bílé, to je dobré“. Balti žmonès „dobří lidé“; balta galwa „dobrá duše“ (doslovně „dobrá hlava“).

Přihlédněme ke skutečnosti, že F. L. Čelakovský předpokládal, že od slova balti je odvozen i etnonymum Baltové. Pokud s tímto výkladem konfrontujeme Čelakovského pokus o odvození původu slova člověk od slova Slovan ve výše zmíněném článku, nalézáme sdělení plně zapadající do obrozeneckých koncepcí, které je zcela $\mathrm{v}$ duchu romantické baltoslovanské vzájemnosti, totiž že „Slované jsou lidé“ a „Baltové jsou dobř́ lidé“.

Z pohledu současné etymologie je takové tvrzení zcela neopodstatněné. Převažující výklad původu slova Baltové (Baltai) vychází z hydronomických pojmenování. Ztotožňuje tento výraz se slovanským blata. Dle Toporovovy teorie původní význam kořenu *balt- odkazoval na „oblast uzavřeného moře“, a mohl nést dvojí význam: „bílýc i „,bažinatý““. ${ }^{44}$ Slovo billý pochází ze všeslovanského základu. Polsky bialy, ukrajinsky bilyj, rusky belyj aj. V. Machek ve svém etymologickém slovníku uvádí, že staroslovenské bèlt má protějšek v řeckém $\beta \alpha \lambda$ lós, bílý, běloskvrnatý, což je př́buzné s litevským baltas. ${ }^{45}$

Co se týče slova člověk, musíme uvést, že na jiném místě Litevského slovniku jeho autor nabízí jiný výklad než ve výše zmíněném článku. Viz heslo: člověk (230. v celkovém pořadí, 54 . ve skupině pod písmenem Č):

„,̌clověk, žmogus, -aus, m.; žmonis, -ẽs, m.; toto druhé jen v plur. v obyčeji: žmones, lidé; duszia, ne žmogus, anděl, ne člověk; žmogyste, -ẽs, f., člověčenství; žmogẽdis, -dzio, $\mathrm{m}$. lidojed /místo ,žmonis" přichází ve starších spisech také zkrácené „こ̌mu““. Etymologii slova toho v „Pott de Lith. Bor.

\footnotetext{
${ }^{43}$ Litevský slovnik, Knihovna Národního muzea, oddělení rukopisů a starých tisků, sign. IV A 11. Heslo: bíliti.

${ }^{44}$ Více o etymologickém výkladu původu názvu Balt viz: DINI 2014, s. 37-42.

${ }^{45}$ MACHEK 1957, s. 54. Heslo: bílý.
} 
Principatu“, p. 64, 65/ : žmona, -õs, f., žena, člověčice; žmonyste, -ẽs, f., člověčenství. - lot. zilweks."46

Polský jazykovědec W. Smoczyński k původu litevského žmogus nabízí tento výklad: „Litevské žmogus je novotvar vytvořený př́ponou -g-od původního žmuo, acc. sg. žmunį, odvozené z kořenu žemè (země), znamenající ,zemės gyventojas', obyvatel země. [...] Lotyšské cilvẽks je výpůjčka ze slovanštiny, srov. *čblovékъ. ${ }^{\text {" }}$ "47

$\mathrm{K}$ tomuto doplňujeme vysvětlení, které předkládá V. Machek: „člověk, pol. czlowiek, hl. člowjek, dl. clowjek, ukr. čolovik, r. čelovék, stsl. člověka, sin. člověk, sch. čovjek, b. čovek. - Psi. asi *čelovek*b. [...] Slovo je složenina; v 1. části vězí útvar od nedochovaného čelo gen. čelese tlupa, sdružení, sbor, oddíl (vojáků, hlídačů, lovců, pracovníků,

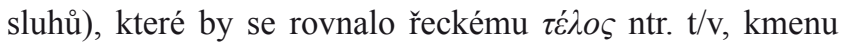
na osjes. [...] Druhá část obsahuje útvar od kořene veik- (viz jej u věc) se stupněm o: ide. *voik-o-s. Celek tedy znamenal ,(muž) činný jakožto člen jisté skupiny“ (zřízené za jistým účelem např. vojska, artělu, služebnictva). ${ }^{\text {"48 }}$

$\mathrm{Na}$ základě těchto výkladů můžeme zkonstatovat, že z hlediska češtiny a litevštiny se nejedná o stejný společný původ, ovšem v případě lotyštiny se jedná o výpůjčku ze slovanského jazyka.

Heslo: Boží dřevce (67. v celkovém pořadí, 8 . ve skupině pod písmenem $B$ ):

„Boží dřevce (artemisia abrotanum) dẽwmédis, -dzio, m. “49

V tomto případě F. L. Čelakovský ztotožňuje lidový název pro pelyněk s jeho litevským protějškem. Tuto snahu hodnotíme jako sémanticky opodstatněnou. Označení pelyňku je i v současné litevštině: dievmedis, jedná se o kompozitum dvou slov dievas (bůh) a medis (strom). V. Machek o pelyňku uvádí následující: ,pelyněk, nář. pelun peluň(ek) pelyn̆ poly-nek polének polin palin. - Sic. polynok, pol. piolun, ukr. polyn, r. dl. polyn̆ $-n$, hl. polon, sin. sch. b. pelin. - Není jisto, jak zněla přesně psi. podoba. Jestliže pel-um>, lze snad v pelviděti týž kořen, co je $\mathrm{v}$ páliti a $\mathrm{v}-u m>$ př́ponou činitelskou jako v běh-oun. Lze se opř́ti o lit. kietis ,Černobýl' (druh pelyňku), jež možno spojit s kalsti, planouti‘, a o něm. Wermuth ,pelyněk', patřící zajisté k warm ,horký‘. Tyto souvislosti mají základ v dávném léčitelském prostředku, zvaném moxa, dosud oblíbeném v Asii: rozpálené kuželíky z pelyňku se přikládají na určitých místech na kůži nemocného [...]. U nás moxa doznívá snad v sázení baněk (viz báň); kromě toho tyto tři názvy peluně mohou být svědectvím, že byla v předhistorické době známa i u Slovanů, Baltů a Germánů. “50
Heslo: cibule (168. v celkovém pořadí, 1. ve skupině pod písmenem C):

„cibule, cibullis, -io, m.; laukinis cibullis, die Zeitlose.“

Podle A. Sabaliauskase lexém cibulis přešel do litevštiny z polštiny nebo běloruštiny. ${ }^{51}$ Takový výklad nabízí i W. Smoczyński. ${ }^{52}$ Jedná se tedy o slavismus. Spisovný název označující cibuli je svogūnas. Kromě botanického názvu však můžeme $\mathrm{v}$ tomto př́padě poukázat na přenesený význam cibulí, jakožto kapesních hodinek, které v litevštině taktéž označuje lexém cibùlis. ${ }^{53}$ Německá poznámka die Zeitlose upřesňuje termín laukinis cibulis, tedy: „divoká cibule“, v tomto př́padě se jedná o ocún jesenní.

Heslo: hvězda (441. v celkovém pořadí, 74 . ve skupině pod písmenem $\mathrm{H}, \mathrm{z})$ :

„hvězda, žwaigžde, žwaigzde, -ẽs, f.; žwaigždẽtas, - $a$ hvězdnatý, neb i s hvězdou; žwaigždininkas, -o, m. (hvězdník), vykladač z hvězd; klystžwaigždéle, -ẽs; klystžwaigždykle, -ẽs, f. (bludná hvězdička, bludička). “54

V tomto př́padě Čelakovský postihl významnou baltoslovanskou shodu. Lexémům odpovídá staroslovanské zvězda. Základem byl slovesný kořen, který se nezachoval u Slovanů, ale který je v litevském dvazgèti „třpytiti se, záŕiti““.55 Velký slovník litevštiny spojuje lexém klystžwaigždyklè s klystugnè, tj. bludným ohněm, bludičkou. ${ }^{56}$ Jedná se tedy o stat', která nabízí jedno z řady do Slovníku zařazených mytonym.

\section{Závěr}

Archiválie Litevský slovník (sign. IV A 11) uložená v oddělení rukopisů a starých tisků Knihovny Národního muzea vyžaduje komplexní analýzy, jež zahrnují jak studium primárních zdrojů, tak i přihlédnutí k širšímu kontextu vývoje české filologie a národního obrození. Stěžejní je otázka autorství této památky. Litevský slovník dobře zapadá do kontextu zájmů i filologických postojů významné osobnosti české literatury a vědy, zakladatele české baltistiky a prvního profesora slavistiky na Pražské universitě F. L. Čelakovského. Za zásadní indicie, na základě nichž je možné přiřknout autorství F. L Čelakovskému, považujeme:

1) korespondenci tohoto obrozence, v níž je prokazatelný zájem o baltskou látku, především fragment dopisu J. V. Kamarýta určený F. L. Čelakovskému, kde se přímo hovoří o litevském slovníku;

2) typologicky podobné lexikografické aktivity F. L. Čelakovského, mezi něž Litevský slovník velmi dobře zapadá;

\footnotetext{
${ }^{46}$ Litevský slovník, Knihovna Národního muzea, oddělení rukopisů a starých tisků, sign. IV A 11. Heslo: člověk.

${ }^{47}$ SMOCZYŃSKI 1982, s. 221. (Dostupné z: http://etimologija.baltnexus.lt/?w=\%C5\%BEmogus)

${ }^{48}$ MACHEK 1957, s. 105. Heslo: člověk.

${ }^{49}$ Litevský slovník, Knihovna Národního muzea, oddělení rukopisů a starých tisků, sign. IV A 11. Heslo: Boží dřevce.

${ }^{50}$ MACHEK 1957, s. 443. Heslo: pelyněk.

${ }^{51}$ SABALIAUSKAS 1958, s. 171-177. (Dostupné z: http://etimologija.baltnexus.lt/?w=cibulis)

${ }^{52}$ SEJL, s. 227. Heslo: cibùlis.

${ }^{53}$ LKŽ. Heslo: cibulis. (Dostupné z: http://www.lkz.lt)

${ }^{54}$ Litevský slovnik, Knihovna Národního muzea, oddělení rukopisů a starých tisků, sign. IV A 11. Heslo: hvězda.

${ }^{55}$ Podrobněji MACHEK 1957, s. 192. Heslo: hvězda; SEJL, s. 2099-2100. Heslo: žvaigždè.

${ }^{56}$ Viz LKŽ. Heslo: klýstžvaigzdykle; heslo: klýstžvaigzdè. (Dostupné z: http://www.lkz.lt)
} 
3) myšlenková totožnost patrná jak v Litevském slovní$k u$, tak v jiných dílech F. L. Čelakovského;

4) vyloučení jiných osobností, jež by mohly Litevský slovník sepsat, z pozice možného autora.

Na základě dat z korespondence, vkontextu Čelakovského překladatelských zájmů a další lexikografické činnosti můžeme vyjádřit předpoklad, že autor na Litevském slovníku začal pracovat kolem roku 1825 (pravděpodobně v podobě Výtahu slov z Ruhigova slovniku stejnokořenných se slovanskými, který se zachoval v opise P. J. Šafař́ka z roku 1833) a v dalších letech jej dokončoval. Podle pravopisu užitého ve zkoumaném díle a díky výkladové vsuvce pořízené podle Nesselmannova slovníku během roku 1851 však soudíme, že základní text analyzované verze Litevského slovníku byl sestaven kolem roku 1850.

Nový př́nos ve věci určení autorství má písmoznalecký posudek vypracovaný JUDr. J. Strakou. Tento posudek sice nepřinesl stoprocentní jistotu, přesto J. Straka určil F. L. Čelakovského jako autora v rovině ,střední pravděpodobnosti“. Posudek tak spolu s ostatními doklady tvoří významný argumentační bod svědčící pro autorství $\mathrm{F}$. L. Čelakovského.

Nicméně musíme vést v patrnosti, že v otázce autorství samotného Slovníku (z hlediska koncepčně obsahového) písmoznalecký posudek není samospasný a zcela směrodatný. Zaručeným dokladem autorství by byl pouze $\mathrm{v}$ případě, kdy by poskytl naprostou jistotu při identifikaci předpokládaného autora rukopisu. Ovšem ani v př́padě, kdy by písmoznalecký posudek F. L. Čelakovského vyloučil jako pisatele námi disponované verze Litevského slovníku, neznamenalo by to zavržení F. L. Čelakovského jako autora této památky. Musíme zvažovat zcela reálnou možnost, že původní Slovník tvořený ve 20. letech 19. století do současné podoby kolem roku 1851 přepsala jiná osobnost filologické scény, např. některý z Čelakovského následovníků, nebo obyčejný přepisovatel v souvislosti s nerealizovaným edičním záměrem.

V každém případě $\mathrm{s}$ ohledem na soubor veškerých předložených zjištění a argumentů musíme konstatovat, že se autorství F. L. Čelakovského jeví jako prokázané.

\section{Prameny:}

Litevský slovnik. Knihovna Národního muzea, oddělení rukopisů a starých tisků, sign. IV A 11.

Wýpisky o gazyku litewském. Knihovna Národního muzea, oddělení rukopisů a starých tisků, sign. IX E 4.

Literární archiv Památníku národního písemnictví, fond F. L. Čelakovský.

Literární archiv Památníku národního písemnictví, fond J. V. Kamarýt.

BÍLÝ 1907-1909: BÍLÝ, František (ed.). Korespondence a zápisky Frant. Ladislava Čelakovského 1. Praha: Česká akademie věd, 1907-1909.

BÍLÝ 1907-1935: BÍLÝ, František (ed.). Korespondence a zápisky Frant. Ladislava Čelakovského 1-4. Praha: Česká akademie věd, 1907-1935.

ČELAKOVSKÝ 1825: ČELAKOVSKÝ, František Ladislav. Slovanské národni písně. Praha: Písmem J. Vetterlové z Wildenbrunu, 1825.
ČELAKOVSKÝ 1827: ČELAKOVSKÝ, František Ladislav. Litevské národni pisně. Praha: Jan Host. Pospíšil, 1827.

ČELAKOVSKÝ 1837: ČELAKOVSKÝ, František Ladislav. Jazykozpytné rozmlouvání o jménu Slovan. Časopis Českého museum 11, 1837, s. 53-67.

ČELAKOVSKÝ 1852: ČELAKOVSKÝ, František Ladislav. Mudrosloví národu slovanského ve príslovich. Praha: František Řivnáč, 1852.

ČELAKOVSKÝ 1853: ČELAKOVSKÝ, František Ladislav. Čtení o srovnávací mluvnici slovanské na universitě pražské. Praha: František Řivnáč, 1853.

ČELAKOVSKÝ 1877: ČELAKOVSKÝ, František Ladislav. Čteni o počátcích dějin vzdělanosti a literatury národúv slovanských. Praha: Nákl. Musea Království českého, 1877.

LEMEŠKIN 2018: LEMEŠKIN, Ilja. Vyjádření k psané podobě „Litevského slovníku“. Praha, 2018.

STRAKA 2018: STRAKA, Jiří. Znalecký posudek z oboru písmoznalectví, specializace ruční písmo, zabývajicí se otázkou zda predmětnou archiválii, tj. Litevský slovnik (sing.: IV A 11), jehož originál je uložený v Oddělení rukopisů a starých tiski̊ Knihovny Národního muzea, napsal František Ladislav Čelakovský, narozený 7. brezna 1799 a zemřelý dne 5. srpna 1852. Praha, 2018.

\section{Literatura:}

BARTOŠ 1926: BARTOŠ, František Michálek. Soupis rukopisů Národního musea v Praze. Svazek I. Praha: Melantrich, 1926.

BĚTÁKOVÁ - BLAŽEK 2012: BĚTÁKOVÁ, Marta Eva - BLAŽEK, Václav. Encyklopedie baltské mytologie. Praha: Libri, 2012.

BÍLÝ 1899: BíLÝ, František. O filologickém vývoji Fr. Lad. Čelakovského: Přednáška Fr. Bílého, konaná v Jednotě českých filologů na památku stých narozenin Čelakovského dne 25. února 1899. Listy filologické 26, 1899, č. 2, s. 103-116. ČELADÍN - BLAŽEK - KABELÁČOVÁ - SEITLOVÁ 2016: ČELADÍN, Jindřich - BLAŽEK, Václav KABELÁČOVÁ, Tereza - SEITLOVÁ, Eva. Čekų baltistikos bibliografija. In: Acta Linguistica Lithuanica 74, 2016, s. 305-351.

DINI 2014: DINI, Pietro Umberto. Foundations of Baltic languages. Vilnius: Eugrimas, 2014.

ERBEN 2009: ERBEN, Karel Jaromír et al. Slovanské bájesloví. Praha: Etnologický ústav, Slovanský ústav AV ČR, 2009.

FRANCEV 1901: FRANCEV, Vladimir Andrejevič. Ostatki jazyka slavjan polabskich, sobrannyje i objasnennyje F. L. Čelakovskim. Petrohrad, 1901.

HANUŠ 1855: HANUŠ, Ignác Jan. Život a pưsobení Františka Ladislava Čelakovského. Praha: [s. n.], 1855.

JUNGMANN 1839: JUNGMANN Josef. Slovník česko-německý, Díl V., $V-Z$. Praha, 1839.

LEMEŠKIN 2008: LEMEŠKIN, Ilja. Augustas Schleicheris ir Praha. In: Lituanistinis Augusto Schleicherio palikimas. T. 1. Vilnius: Lietuvių kalbos institutas, 2008, s. 63-102.

LEMEŠKIN 2010: LEMEŠKIN, Ilja. Františeko Ladislavo Čelakovskio lietuvių kalbos žodynas. In: Leksikografija 
ir leksikologija. Vilnius: Lietuvių kalbos institutas, 2010, s. 98-113.

MARVAN 2004: MARVAN, Jiří. Čelakovský stále mezi námi (K odkazu F. L. Čelakovského a jeho následovníků). In: Pocta Čelakovskému. Př́spěvky ze sympozia k 200. výroči narození zakladatele české baltistiky Františka Ladislava Čelakovského. Praha: Univerzita Karlova, 2004, s. 11-18.

MARVAN - ŠTOLL 2004: MARVAN, Jiří - ŠTOLL, Pavel (edd.). Pocta Čelakovskému. Přispěvky ze sympozia k 200. výroči narozeni zakladatele české baltistiky Františka Ladislava Čelakovského. Praha: Univerzita Karlova, 2004.

MACHEK 1957: MACHEK, Václav. Etymologický slovník jazyka českého a slovenského. Praha: ČSAV, 1957.

ŘEHÁČEK 1981: ŘEHÁČEK, Luboš. Baltistika na pražské univerzitě (1848-1978). Praha - Vilnius. Sborník prací $k$ 400. výroči založení univerzity ve Vilniusu. Praha: Univerzita Karlova v Praze, 1981, s. 45-63.

SABALIAUSKAS 1958: SABALIAUSKAS, Algirdas. Dél baltų kalbu svogūno pavadinimu kilmès. LMAD, 1958, II (V), s. 171-177. (Dostupné z: http://etimologija.baltnexus. lt $/ ? w=$ cibulis)

SEDLÁČEK 1993: SEDLÁČEK, Miroslav. K vývoji českého pravopisu. Část 1. Naše řeč 76, 1993, s. 57-71. (Dostupné z: http://nase-rec.ujc.cas.cz/archiv. php?lang=en\&art=7120)

SMOCZYŃSKI 1982: SMOCZYŃSKI, Wojciech. Indoeuropejskie podstawy słownictwa battyckiego. ABSI 1982, s. 221 (Dostupné z: http://etimologija.baltnexus. lt $/ ? w=\%$ C $5 \%$ BEmogus)
SMOCZYŃSKI 2007: SMOCZYŃSKI, Wojciech. Lietuviu kalbos etimologinis žodynas. Vilnius: Vilniaus universitetas, filologijos fakultetas, 2007.

ŠEFERIS 2009: ŠEFERIS, Vaidas. Kristijono Donelaičio kūryba čekų filologijos akiratyje. In: Senoji Lietuvos literatūra 28, 2009, s. 41-62.

TOLLAROVÁ 2016: TOLLAROVÁ, Anna. Rukopisný slovník litevštiny z první poloviny 19. století z Knihovny Národního muzea. Praha, 2016. Bakalářská práce. Univerzita Karlova. Filozofická fakulta.

\section{Elektronické zdroje:}

Lietuviu kalbos etimologinio žodyno duomenu baze [online]. Vilniaus universiteto Filologijos fakultetas. Dostupné z: http://etimologija.baltnexus.lt/

LKŽ: Lietuvių kalbos žodynas [online]. Lietuvių kalbos institutas. Dostupné z: http://www.lkz.lt

SEJL: SMOCZYŃSKI, Wojciech. Słownik etymologiczny języka litewskiego [online]. Digitální verze slovníku. Dostupné z: http://rromanes.org/pub/alii/ Smoczy\%C5\%84ski\%20W.\%20S\%C5\%82ownik\%20etymologiczny\%20j\%C4\%99zyka\%20litewskiego.pdf

\section{| Anna Tollarová \\ Univerzita Karlova \\ Filozofická fakulta \\ nám. Jana Palacha 2 \\ 11638 Praha 1}

